\title{
ORGANIZATION OF THE ACCESS DATABASE FOR THE LOJANE Sb-As MINE WASTE DUMP, REPUBLIC OF NORTH MACEDONIA
}

\author{
Assoc. Prof. Dr. Goran Tasev ${ }^{1}$ \\ Doc. Dr. Dalibor Serafimovski ${ }^{2}$ \\ Doc. Dr. Vančo Adžiski ${ }^{1}$ \\ Doc. Dr. Todor Čekerovski \\ Full Prof. Dr. Todor Serafimovski ${ }^{1}$ \\ ${ }^{1}$ Faculty of Natural and Technical Sciences, University "Goce Delčev"- Štip, R. N. Macedonia \\ ${ }^{2}$ Faculty of Electrical engineering, University "Goce Delčev"-Štip, R. N. Macedonia
}

\begin{abstract}
Organization of the Access database of the Lojane As-Sb deposit Northern Macedonia represents the first attempt of this paper authors to synthesize geological exploration data of this ore bearing locality in one professional database available for the interested parties. Since we are relatively experienced in compiling similar databases for numerous deposits (Bucim, Borov Dol, Kadiica, Sasa etc.), we had a critical knowledge needed to to organize representative Access database for the Lojane deposit. The Lojane deposit, which as As, Sb and Cr mine was exploited in the period 1923-1979, is located close to the northern state border of the Republic of North Macedonia, close to the border with Kosovo and in the immediate vicinity of the Lojane and Vaksince villages. During the processing period flotation was used for concentration of antimony and arsenic minerals, which resulted in significant amount of tailings. Tailings pile disposed close to the processing plant reached up to 450000 tons of waste material and covers an impressive area of $17500 \mathrm{~m}^{2}$. Also, within concentrate storage pond build near the plant (approx. $5000 \mathrm{~m}^{3}$ in volume) had been disposed 15000 tons of arsenic concentrate with min. 50\% As as well as $3000000 \mathrm{t}$ of tailings remaining at the concentration facility. High concentration of arsenic sulfides, in uncovered tailing dam, is indicated by its intensive orange color as well as intensive odor.. Within ours paper we focused to a compilation of an anthropogenic data of the Lojane deposit in a representative Microsoft Access database. Using well known database software package "Microsoft Access" we started compilation of ours work with filling fields with general information, wastes and products, iconography and bibliography. We must to stress that ours particular Lojane anthropogenic database provides simple and user-friendly querying of certain features and creation of editable reports as well as geographic display that information. Distinctive data representative for this particular anthropogenic database accented several inevitable facts: the production facility is inactive, the location is waste dump of former facility, significant quantities of arsenic (900 t), antimony (803 t), nickel (315 t), molybdenum (3.6 t) and thallium (2.7 t) accented the economic parameters of the location.
\end{abstract}

Keywords: Lojane As-Sb deposit, Access database, anthropogenic, economy. 


\section{INTRODUCTION}

Between the villages of Lojane and Vaksince on the northern part of the Republic of North Macedonia is located former Sb-As deposit Lojane. Mine exploitation of As, Sb and $\mathrm{Cr}$ took place between 1923 and 1979. On the junction of the andesite and serpentinite, serving as ore knots, steep NW-SE veins were excavated for Sb and As [1], [2], [3]. Productive veins were long $0.5 \mathrm{~km}$ while their thicknesses varied between from 1 to $2 \mathrm{~m}$. Several minerals were characterized as major ore mineralization: As-Sb sulfides (orpiment, realgar, stibnite), while some other such are bravoite $\left((\mathrm{Fe}, \mathrm{Ni}, \mathrm{Co}) \mathrm{S}_{2}\right)$, vaesite $\left(\mathrm{NiS}_{2}\right)$, cattierite $\left(\mathrm{CoS}_{2}\right)$, pyrite, marcasite, molybdenite and pitchblende $\left(\mathrm{UO}_{2}\right)$ occur as associated minerals in lower quantities. Quartz and sporadically dolomite were characterized as waste. Occasionally oxidized primary sulphides resulted in secondary oxides and hydroxides. At the mine location waste material reached up to $20000 \mathrm{t}$ [2]. Figure 1 gives an insight to the waste dump of the former Lojane Sb-As mine.

After the ore had been excavated it was transported from the underground workings to the mill and flotation plant and then exported by rail. During the period of active processing of the mine, flotation concentration of antimony and arsenic minerals produced tailings disposed just in front of the plant (Figure 1). As it was stressed [1],[2],[3], tailings pile covers a surface of app. $17500 \mathrm{~m}^{2}$, and contains app. 450000 tons of sludge material while the concentrate storage pond in the plant's near vicinity encloses 15000 tons of arsenic concentrate with up to 50\% As followed by impressive $3000000 \mathrm{t}$ of tailings at the concentration facility [2]. High concentration of arsenic sulfides, in uncovered tailing dam, is indicated by its intensive orange color and intensive odor. By the narrow railway, across the agricultural area, concentrate was transported to a location next to the main railway line at Civluk. At Civluk there are also the remains of the old arsenic smelter.
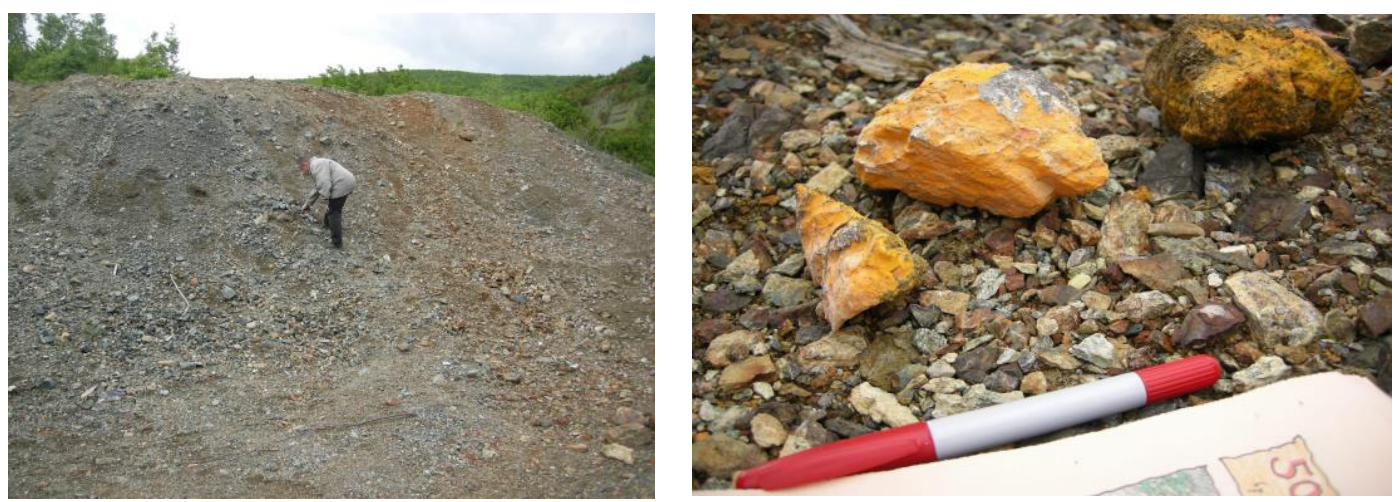

Fig. 1. Sampling former Lojane Sb-As waste dump, Republic of Macedonia.

An area of the former smelter facility is occupied by large pile of arsenic concentrate and covered by numerous heaps of black and white powdery material. Chemical analyses confirmed stibnite concentrate and refined 'white arsenic' (arsenolite, $\mathrm{As}_{2} \mathrm{O}_{3}$ ) and are attributed to the remains of 2500 decomposed wooden barrels of processed material left unattended during the recent conflict and rot [4], in a storage area covering $8,800 \mathrm{~m}^{2}$. The most notable publications, up to date, regarding the Lojane mine, its former production and lately on pollution, were contributed by [1], [2], [3], [4], [5] and [6].

Until recently, in the Republic of North Macedonia, professional databases structured by European legislative, did not existed. Lately Ministry of Economy initiated an action 
that such database(s) must be compiled in accordance to already existing similar modern European databases (ex. BRGM Mineral database). We strived to devise and organize database filled up with information regarding the most potentially anthropogenic concentrations (eg. waste dumps), such waste dump of the Lojane Sb-As deposit is. Due to fact of several decades of exploration and exploitation of the Lojane deposit, we assumed that compiling aforementioned database would not be an easy task to achieve. Extremely intensive data collected during five decades needed to be processed. The Access database was structured at several layers as main topics and it is compatible with several GIS mineral databases Worldwide [7], [8], [9], [10], [11], [12], [13].

\section{DISCUSSION}

As we already pointed out, the anthropogenic concentrations Access database displays its several organizational entities:

General information part or layer contains an information about the location of the deposit occurence, legal and operational status, as well as latitude/longitude, ore district name, comments etc. (Figure 1).

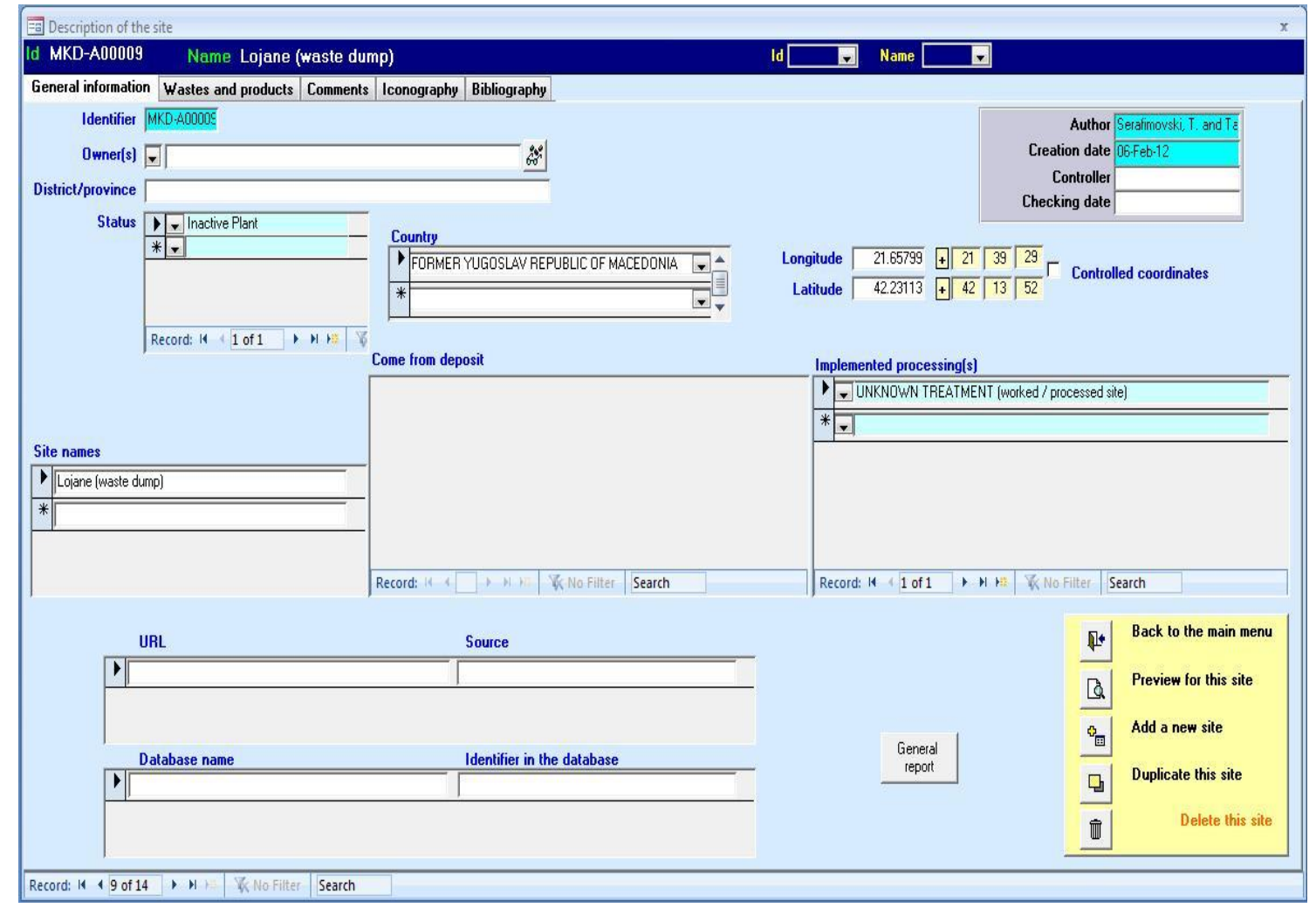

Fig. 1. General information datasheet of the anthropogenic database

The database for our particular Lojane Sb-As deposit waste dump we stressed out that is a an former facility with ceased mine activities followed by description of used processing methods, and that is a prospective anthropogenic deposit with certain potentials in regards to $\mathrm{Cr}$, Sb and As. Also, we have included information such are detailed coordinates, name of the company owner of the former mine and former production facility, as well as familiar names used by locals for the mine and short general comments. 
Wastes and products section was organized as data sheet/layer that gives, to an interested parties, details such are: storage type (surface, underground,...), waste type (mine waste dump, slag,...), occupied volume and surface as well as tonnage and density of a particular waste-product, detailed mineralogy of the waste, and eventually pollution affected water area (Figure 2). In this data sheet we gave an accent to certain metals as specific anthropogenic commodities (e.g. Sb, As, Tl, Ni, Mo,...). They inevitably are by-product of particuar host minerals present in the deposit, as well as grades (i.e. minimum, maximum and average grades) and abundance of host minerals in anthropogenic products. In ours case study Lojane, we filled this part of the database with plentiful mineral asseblage of Sb-As-Tl-Fe (stibnite, realgar, orpiment, rozenite, bravoite, pyrite, marcasite, cinnabar, chromite, romeite etc.). We put an accent to the large quantities of $\mathrm{As}, \mathrm{Sb}, \mathrm{Ni}$, Mo and $\mathrm{Tl}$ reaching very promising potential of 900 tons arsenic, 803 tons antimony, 315 tons nickel, 3.6 tons molybdenum as well as 2.7 tons thallium.

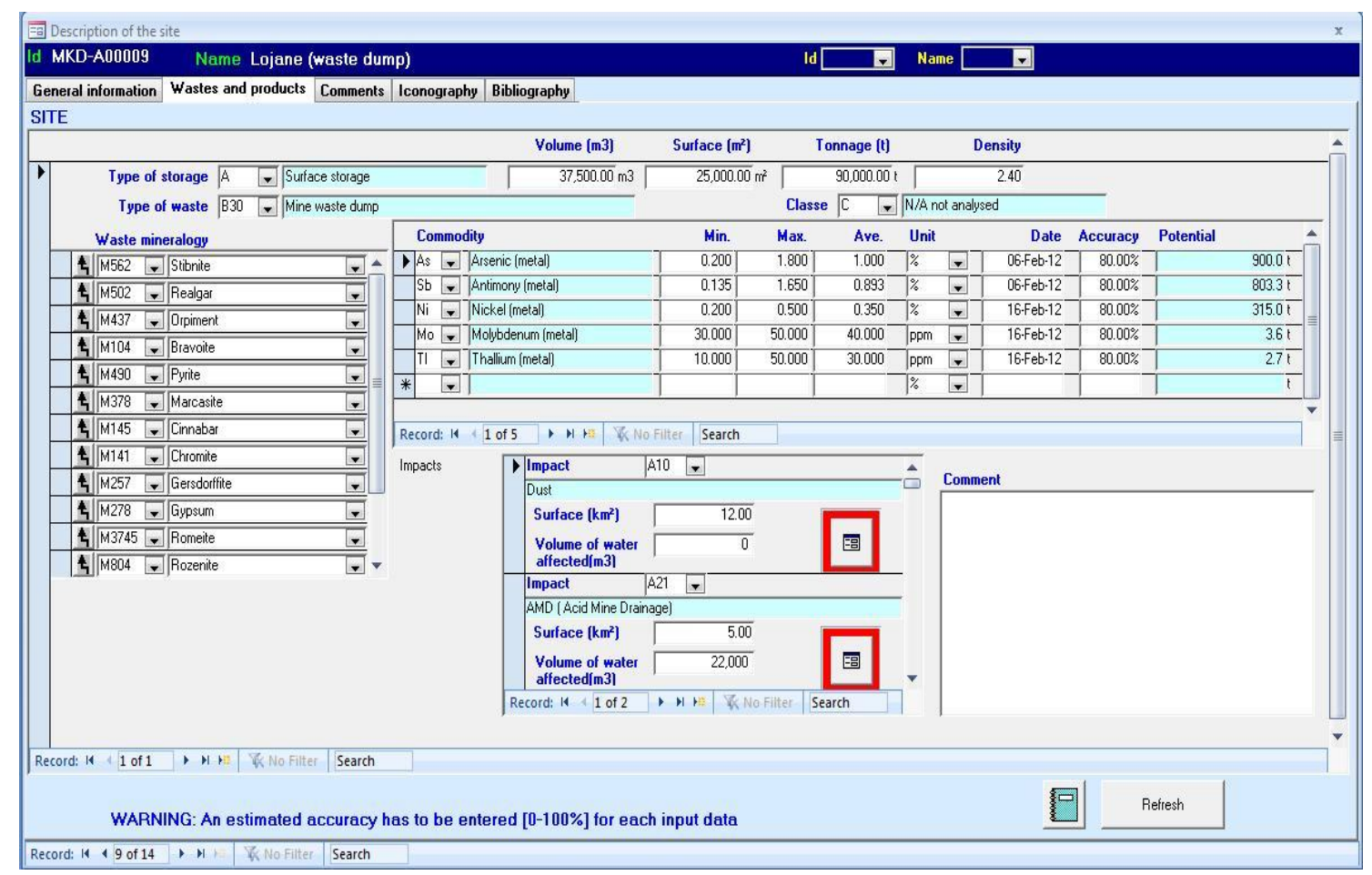

Fig. 2. Wastes and products datasheet of the anthropogenic database

Comments sheet, in general is devised and organized as place in the database where the author(s) may cotribute with free texts describing certain details concerning geology, economy of a particular anthropogene deposit (Figure 3). In ours case study database of anthropogene introduced potential material, around the Lojane deposit, we accented latest data regarding type, size, geology and geological setting of the deposit related to the anthropogenic concentrations itsels. Historical data of the mining stages of the Lojane locality (since 1881 until 1965 with certain period of stopage) was given too. Also, here we included an estimate of the economic features of the pile material and other numerous characteristics (past annual mine capacity, quantitative-qualitative features of produced ore etc), see Figure 3. 


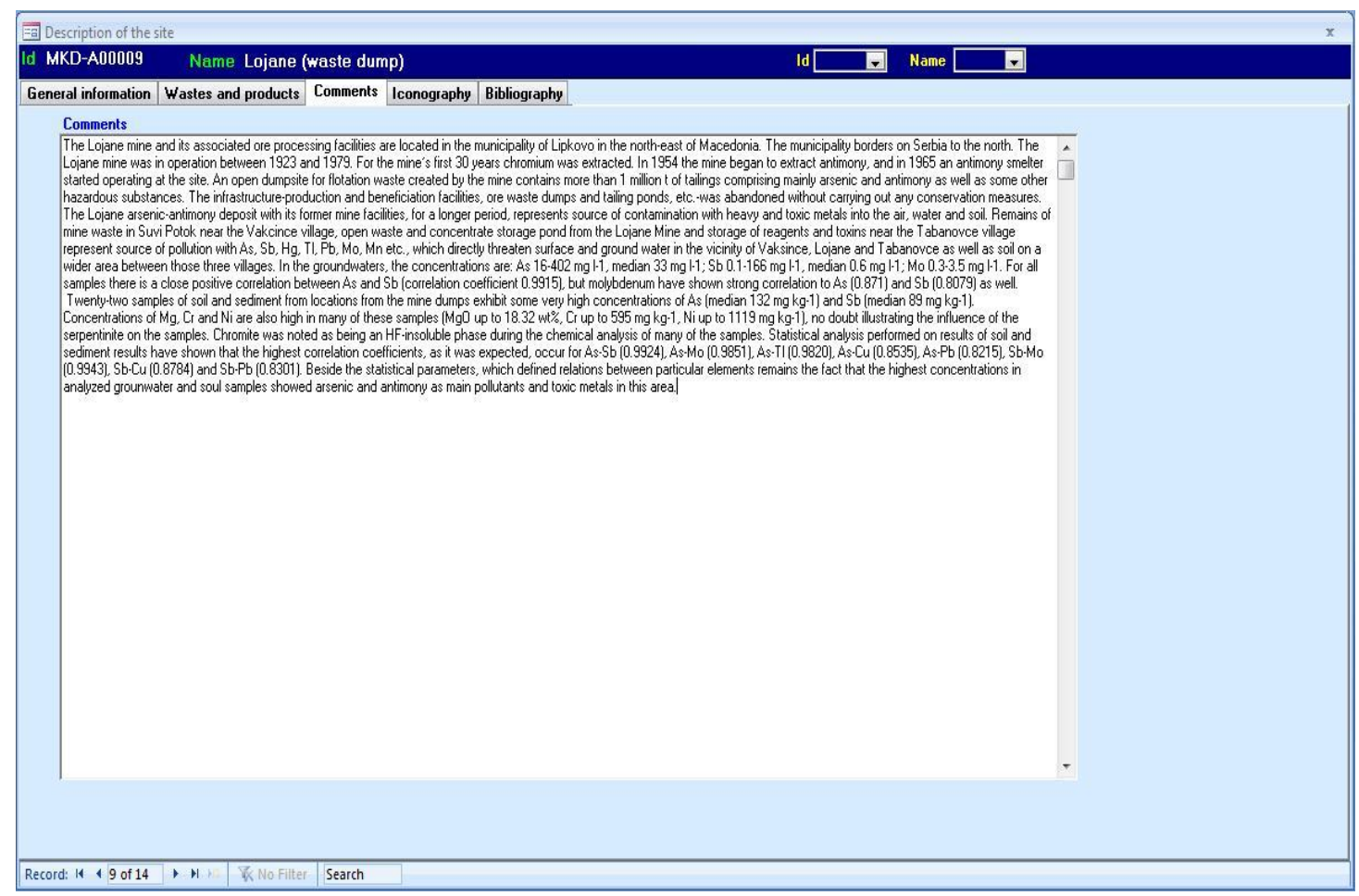

Fig. 3. Comments information datasheet of the anthropogenic database

Iconography sheet was devised and organized in a manner that will enable to include images showing an anthropogenic concentration. In tis sheet primarily we could define the paths of the image directory (at local or distant computer configuration) as well as the proprietary image viewer (e.g. Photo Editor, Windows picture viewer, Picasa...) by pressing "Configuration" option, similar to the mineral database above (Figure 4).

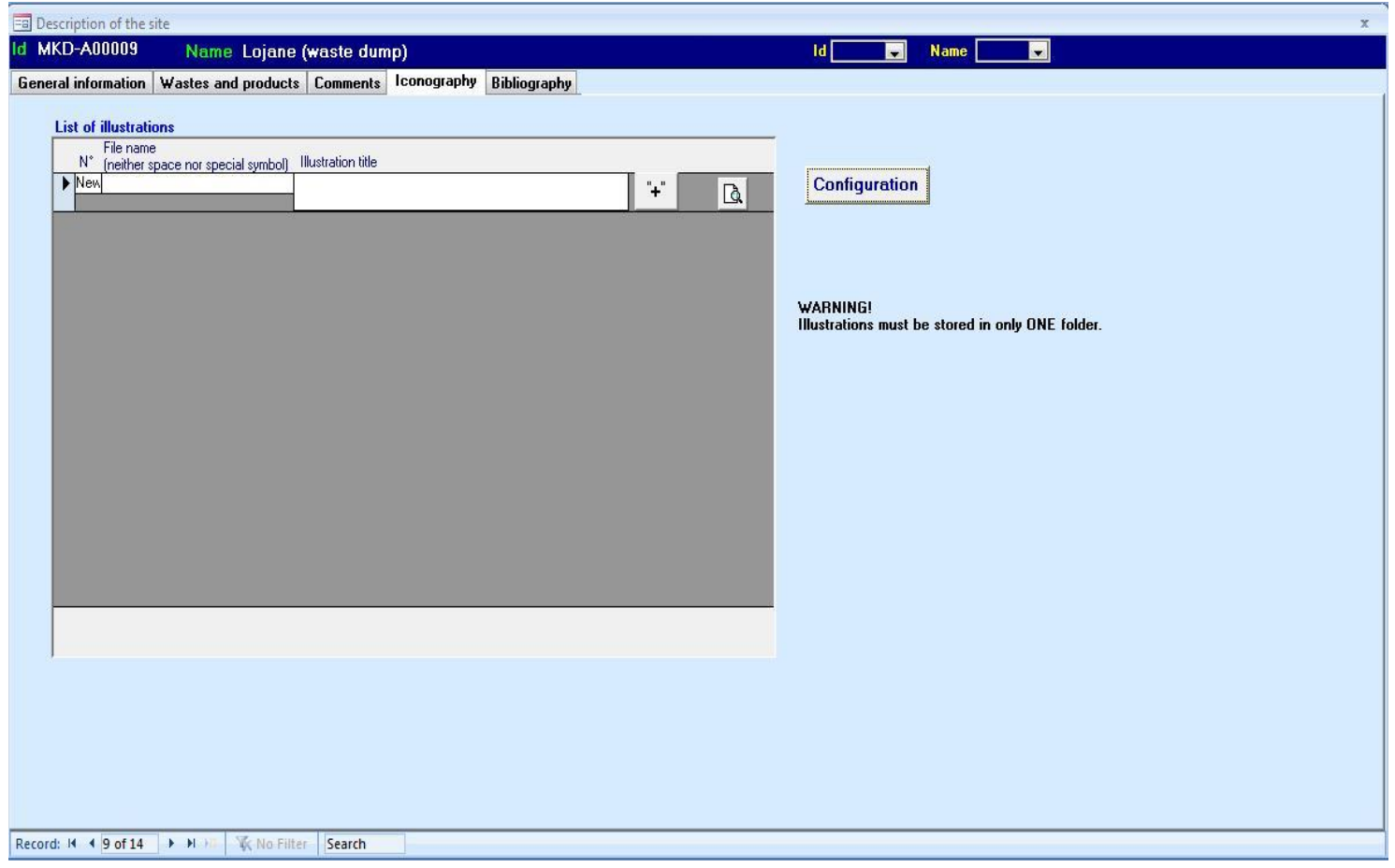

Fig. 4. Iconography information datasheet of the anthropogenic database 
Bibliography data sheet was organized to emphasize up to date available bibliography (related to the particular anthropogenic concentrations) as well as economical bibliography (related to economic data of the anthropogenic concentrations and its predecessor ore deposit), see Figure 5. In organizational manner it was relatively simple and user-friendly, although should be followed by separate file named Bibliography.

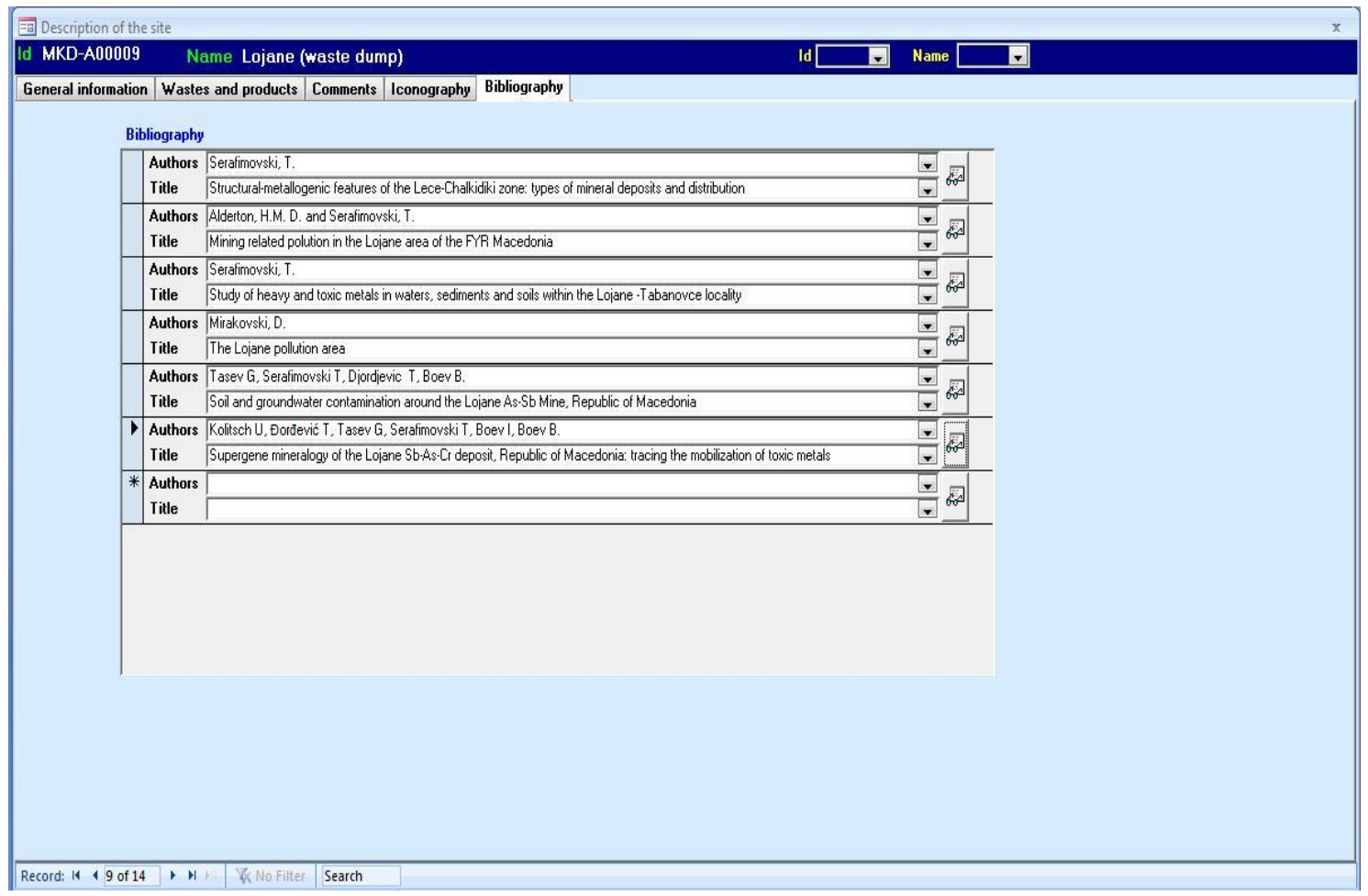

Fig. 5. Bibliography information datasheet of the database

For this particular location we have entered intensive quantity of significant bibliographies, geological and economic ones as well. All the known and commonly used references to this particular deposit have been covered in this data sheet.

\section{CONCLUSION}

The complex process of devising, organization and compilation of the Access database for the Lojane Sb-As mine waste dump aimed at its anthropogenic reflections, mainly accenting its qualitative-quantitative parameters and natural indicators. All that was done in function to present and estimate future valorization of some metals included within the database. All that was performed in accordance with European and Worldwide professional mineral databases. Also, environmental and economic viability of the Lojane waste dump as anthropogenic concentration was estimated. That estimate showed that the waste dump of the abandoned Lojane mine contains promising quantities of $\mathrm{As}, \mathrm{Sb}, \mathrm{Ni}, \mathrm{Mo}$ and $\mathrm{Tl}$ with potential of 900 tons arsenic, 803 tons antimony, 315 tons nickel, 3.6 tons molybdenum as well as 2.7 tons thallium. Those quantities from an economic point of view should not be underestimated even though real values could be $10-15 \%$ lower. 


\section{REFERENCES}

[1] Jankovic, S., 1960. General characteristics of the antimony ore deposits of Yugoslavia (in German). Neues Jahrbuch für Mineralogie - Abhandlungen, 94, 506-538.

[2] Antonovic, A., 1965. Geology, tectonic structure and genesis of the arsenicantimony ore deposits in the Lojane and Nikustak district (Skopska Crna Gora Mts). (in Macedonian) Geological Institute, Skopje, Special Issue no. 1, 77pp.

[3] Serafimovski, T., 1993. Structural-metallogenic features of the Lece-Chalkidiki zone: Types of mineral deposit and distribution. Faculty of Mining, Stip, Special Issue no. 2, 325pp.

[4] Alderton, D.H.M., Serafimovski, T., Mullen, B., Fairall, K.,James, S., 2005. The chemistry of waters associated with metal mining in Macedonia, Mine Water Environ.,V.24,pp.139-149.

[5] Mirakovski, D. and Čermáková, H., 2007. Feasibility study for Lojane Mine, Macedonia Final Report. For: UNDP-Bratislava Regional Centre, 248 p.

[6] Alderton, D., Serafimovski, T., Burns, L. and Tasev, G., 2014. Distribution and mobility of arsenic and antimony at mine sites in FYR Macedonia. Carpathian Journal of Earth and Environmental Sciences, February 2014, Vol. 9, No. 1, p. 43 $-56$

[7] Albert, J.H., and Rossman, A.J., (2001). Workshop statistics: Discovery withdata, a Bayesian approach: Emeryville, Key College Publishing, 350 p.

[8] Barnett, C.T., and Williams, P.M., (2006). Mineral exploration using modern data mining techniques: Society of Economic Geologists, Special Publication 12, p. 295-310

[9] Cassard, D. and Itard, Y. (2003): Metallogenic and envi-ronmental information systems: A modern tool forthe sustainable development of mineral resources.In: Mineral resource base of the Southern Caucasus and sys-tems for its management in the XXI century, NATOScience Series, IV. Earth and Environmental Sciences, 17, 167-180.

[10] Goodchild, M. and Dopal, S., 1989. Accuracy of spatial databases. Taylor \& Francis, London.

[11] Harris, J.R., Wilkinson, L., Heather, K., Fumerton, S.,Bernier, M.A., Ayer, J. and Dahn, R. (2001): Application of GIS processing techniques for producingmineral prospectivity maps-a case study: mesother-mal Au in the Wayze Greenstone Belt, Ontario, Canada. Natural Resources Research, 10, 91-124

[12] Itard, Y., Geiller, M., Cassard, D. and Lips, A.L.W. (2002). Environmental dimension of a regional metallogenic synthesis: a way towards a sustainable extractive industry. GIS in Geology Int. Conference, Vernadsky SGM RAS, November 13-15, 2002, Moscow,Extended abstracts volume, 51-53.

[13] Vuollo, J., Cassard, D., Simons, B. and Seymon, A., (2010). The Earth resource data exchange model (EarthResourceML)-a tool for delivering ProMine and INSPIRE mineral resource data: INSPIRE Conference 2010 Presentation, Krakow, Poland, 37 p 
